Volume 21 (2021) Issue 2

DOI: $10.2478 /$ foli-2021-0013 | 1-20

ISSN (print): 1730-4237 | ISSN (online): 1898-0198

www.wnus.edu.pl/fos

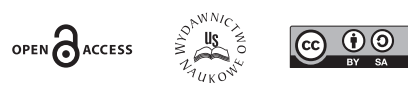

\title{
ABSORPTION RATE AS A TOOL FOR ASSESSING THE DYNAMICS \\ OF DEVELOPMENT ACTIVITY
}

Agata Antczak-Stępniak, Ph.D.

University of Łódź

Faculty of Economics and Sociology

Department of Investment and Real Estate

Ul. POW 3/5, Lódź 90-255

e-mail:agata.antczak@uni.lodz.pl

ORCID: 0000-0002-5858-2774

Received 22 February 2021, Accepted 29 September 2021

\begin{abstract}
Research background: An assessment of the dynamics of the development of the housing market is critical for development activity and the institutions that finance it. Due to the capital intensity of development projects, it seems necessary to perform detailed analyses to be sure that the investment will find buyers and to know how much time it will take for this undertaking to be sold. The absorption rate reports it.

Purpose: The aim of the article is, therefore, to verify the importance of the absorption rate in assessing the dynamics of property market development based on the example of housing development activity in Łódź. Research methodology: To achieve the aim, in the empirical part of the article, information on developers' investments in Łódź was independently collected, and based on them, absorption ratios for several periods were estimated.

Results: The study showed dynamic changes in the absorption rate, as well as its diversity depending on the type of building and location. That is why it is so important to analyze this indicator in developers' activity, where the risk of recovering the capital engaged is very high.

Novelty: In Poland, there are few publications on the given topic, and the existing analyses of the absorption rate in Poland, prepared for the largest Polish cities, do not include the division into specific locations or the type of real estate, which is why they are not sufficiently reliable information for developers.
\end{abstract}

Keywords: development activity, housing market, absorption rate, housing supply, housing demand

JEL calssification: D89, L19, R21, R31 


\section{Introduction}

Free market development activity in Poland has been taking place for only the last 30 years. In this time Polish developers have experienced several declines in their activity that were not only related to the financial crisis or the introduction of new institutional solutions. They also resulted from a lack of market analyzes or their unreliable preparation. Current market analysis is necessary for proper financial assembly, verification of the expected level of rents or prices, and size of effective demand (Peiser, Hamilton, 2012). It also helps developers and other investors make decisions about choosing the best location for implemented projects. The fact that few developers in Poland before the crisis prepared such analyses or that such analyses were quite selective in nature often resulted in the implementation of investments not adapted to the existing market situation or in the general overestimation of investments and possible to achieve profits. It was only the world economic crisis of 2007-2009 and restrictions in the banking system that forced developers to analyze demand and supply in the real estate market, including the absorption rate (perhaps analyzing these indicators would help avoid the wave of developers' bankruptcy that took place then).

In connection with the above, the purpose of this article is to verify the significance of the absorption rate as a tool for assessing the dynamics of the growth of development activity with the example of the Łódź housing market. The diversification according to the type of building and the detailed location of the property will be taken into account in this study.

The main part of the article consists Section 3. The first one presents a theoretical background of the importance the absorption rate for developers. The second section explains the materials and research methods used in the article, and the last one presents the results of the analysis conducted by the author that should confirm the meaning of the spoken indicator for the developer and at the same time, the need for more detailed analyzes in this area. The discussion and conclusions at the end of the article constitute not only a summary of the research carried out, but also indicate their importance for the theory and practice related to the development of real estate.

\section{Absorption rate in the real estate market}

The market, in strictly economic terms, is defined as "a set of conditions that lead to contact between buyers and sellers in the process of exchanging goods and services" (Begg, Fischer, Dornbusch,1993, p. 82). This definition also applies to the real estate market, although some features of both real estate and the real estate market itself that constitute its specificity 
should be remembered. This specificity is revealed, among others, in the fact that the exchange relations concern not only the right to property but also rights related to the use of a given property. Besides, the market mechanism here is limited because many real estate-related issues are subject to state interventionism. It is also one example of a market that is never in a state of equilibrium because demand changes much faster than the supply of real estate (Kucharska-Stasiak, 2016). Nevertheless, the essence of the market definition saying that there must be goods offered for sale (supply) and people willing to buy them (demand) remains true in relation to the real estate market. It should also be noted that supply is an element that is an important factor for the development of the market in the long run, as the construction time for new real estate is relatively long. Demand can change relatively quickly, which is why it is so important for potential investors and developers to track trends related to these market elements. A lack of awareness of how these two variables are shaped in a given area may result in problems with the sale of newly built undertakings.

Supply and demand change over time, which is the result of the cyclicality of the real estate market. Żelazowski (2017) states that it is difficult to clearly define the cycles of the real estate market. Depending on the criteria adopted, e.g. demand and supply cycles or quantitative, volume and price cycles can be distinguished (Żelazowski, 2017). Moreover, the important thing is that the cycles of the real estate market are interrelated with economic cycles and at the same time they outrun economic cycles (Geipele, Kauškale, 2013). The cyclical nature of the real estate market, i.e. maintaining demand, supply and prices during periods of recession, recovery, etc., has been widely recognized in the literature (Mueller, Pevnev, 1997; Mueller, 2001; Pivo, 2006; Reed, Wu, 2010; Gibson \& Li, 2013; Glaeser, 2017; Żelazowski, 2017; Gelain, Lansing, Natvik, 2018). During the oversupply of space, the demand for new space decreases, increasing the number of vacancies. The absorption period extends then. In such a situation, the risk of earning income from real estate increases, which causes a rise in the required rates of return on investment. Higher expected rates of return translate into a decrease in property value. This phenomenon is not favorable for developers. Therefore, the number of newly implemented investments declines. Demand for new space still decreases, and the market continues to be supplied with new space, which is the result of the commissioning of spaces started in the recovery phase. At this time, absorption of space is still low. However, investment activity never drops to zero. The so-called restitution demand contributes to the absorption of oversupply of space on the real estate market. Then the time needed to sell out the offer begins to decline. The improvement in the economic situation contributes to a decrease in unemployment and an increase in the purchasing power of the population. In such a situation, the demand for 
real estate rises again. Moreover, developers, encouraged by the shorter period of absorption of a small amount of space that remains on the market, make new investment decisions (Rottke, Wernecke, 2002; Kucharska-Stasiak, 2016).

Such real estate market volatility makes it necessary to analyze markets before making investment decisions. Market analysis can be defined as a tool for making investment decisions which makes it possible to recognize not only the market situation at a given moment but also to forecast future phenomena (Lipiński, 2000). A great deal of information on the importance of market analysis in development activity can be found in both Polish and foreign literature (cf. Havard, 2014; Raslanas et al., 2015; Millington, 2000; Henneberry, 1987; Novak, 1996; Dąbrowski, Kirejczyk, 2001; Dziworska, Trojanowski, 2006).

According to Dąbrowski and Kirejczyk (2001) one of the key elements of market analysis (along with the analysis of nationwide economic, socio-demographic, political situation, demand and supply forecasts) is the absorption rate.

Greer and Kolbe (2003) state that the absorption rate may be one of the tools for analyzing demand (Greer, Kolbe, 2003). Real estate theories point to the existence of several absorption measures, including gross absorption and net absorption (Floyd, Allen, 1987). The first of them means the total area occupied based on contracts signed in a given period. The second one means changes in the level of occupancy of the offered real estate space (Floyd, Allen, 1987). These ratios are usually used for commercial real estate, where the size of the rented space from which the investor will generate rental income is important. Keim (2007) and Eldred (1987) indicate, however, a different meaning of absorption rate. The definitions they propose refer to the time at which the market absorbs the current supply. Its estimation is particularly important for entities involved in supplying new dwellings to a given market, i.e. developers or other investors (Keim, 2007). It can also be defined as the time it takes for buyers to purchase or lease a given type of space (Eldred, 1987). A similar approach is presented by Frino, Lepone, Mollica and Vassallo (2010), who show that the absorption rate measures the market's ability to sell all properties on offer at a given time. Also, Delauney, Burton and Talpade (2011) define the absorption rate as a time at which dwellings or vacant plots are sold. Letwin (2018) presents a slightly broader definition, taking into account the importance of real estate prices. In his opinion, the absorption rate is the speed at which newly built homes can be sold on the local market, without significantly distorting the market price. He has emphasized the fact that in a situation where the absorption rate begins to rise, developers should not be forced to lower housing prices (especially below their value), because this can cause significant problems not only for the construction industry itself, but potentially also for the entire housing market (Letwin, 2018). This seems to be the 
most adequate definition from the point of view of the efficient functioning of development activity on the housing market.

Why does estimating the absorption rate seem so important? Supply and demand forecasts, which are also part of the market analysis, may not be sufficient, especially in developing real estate markets where access to information is limited. Moreover, in public statistics, sales data (such as supply information) are historical and in Poland some of them have a very short time series. Because the demand for real estate can change very quickly, this type of information must be collected on a regular basis. Having such information (e.g. collected from month to month), makes it possible to find out how much time, given the market conditions, the developer will wait for the return of funds on investment. This seems to be a more reliable basis for making an investment decision than knowing about individual supply and demand data.

Absorption rates in both academic and business practice are characterized by different levels of detail, i.e. they are presented locally or account for the differences between particular building types (Delauney, Burton, Talpade, 2011; Boyd, 2018; Land absorption Study. City of Chico, 2018), and other times they are nationwide - they do not include detailed information related to location or types of buildings (Tse, Webb, 2003; Smith, Verma, Manrique, 2012).

In Poland, where access to information is limited due to the fact that the real estate market is just developing, absorption rate analyses are usually of a general nature. Some sources of information about the residential real estate market in Poland indicate the time of sale of offers for major cities. In the annual reports of the National Bank of Poland, this kind of information from 2012 (Narodowy Bank Polski, 2019) can be found, and up to the first quarter of 2017, REAS also published data on the time of sale of the developers dwellings (REAS, 2017). None of these sources did include the breakdown of this indicator discussed by the type of building or detailed location of the property (districts), which, as indicated earlier based on the foreign literature, is significant for the growth of development activity.

It should be noted that having information about demand and supply, it is also possible to estimate what part of the existing demand will be consumed by a given development project, which is referred to as the capture rate (Creedy, Wall, 1979). The capture rate is the percentage share of the demand on a given market that has been absorbed by a specific project (the number of residential units sold per month). For example, if a developer's investment consists of 200 apartments and the total supply on a given market is 2,000 apartments, it should be assumed that the capture rate is $10 \%$ (Peiser, Hamilton, 2012). Therefore, this indicator can be estimated only from the point of view of a specific project. For this reason, it will not be included in any further analysis. 


\section{Materials and methods}

Quantitative research on the real estate market has many limitations. This is due to the fact that it is characterized by imperfection, manifested primarily in limited access to information and a lack of comparability of many data, especially between different countries, as well as the unpredictability of various events or behavior of market participants. These problems are highlighted by, among others: Antczak-Stępniak (2019), Perera, Higgins, and Wong (2018) or McAllister and Nase (2020). It should be noted, therefore, that the limitations associated with the information obtained are reflected in the results obtained. Firstly, due to the complexity of the analysis taking into account the size of dwellings, especially in the context of the fact that the research periods adopted in this article are mainly of a monthly nature (studies were carried out at the beginning of each month to ensure greater comparability of results), the results presented in the next Section include only a division into the form of buildings and detailed location (city districts). Secondly, this complexity was also the reason for the time limit of the study (three months of 2020 + on an annual basis - April 2018, 2019 and 2020). Thirdly, as mentioned in the previous paragraph, there are several indicators for measuring absorption, but for the sake of clarity only one of them was used. It is assumed, after Keim (2007), that the absorption rate is the time needed for the market to absorb the existing and planned supply or, in other words, the time it takes to sell dwellings on offer in a given local market (after Delauney, Burton and Talpade (2011) and to a large extent also Letwin (2018)). Therefore, the absorption rate discussed above will be estimated as (see Peiser, Hamilton, 2012):

where:

$$
A R=\frac{s}{(\text { monthly }) d}
$$

$$
\begin{aligned}
& s \text { - estimated supply, } \\
& d \text { - estimated demand. }
\end{aligned}
$$

The adoption of this absorption measurement ratio was due to the fact that Peiser and Hamilton (2012) also discussed it in relation to the housing real estate market.

It should be borne in mind that in order to estimate supply (s) for the absorption rate, it is necessary to analyse three types of investments (compare Peiser, Hamilton, 2012):

- completed with vacant dwellings still available for sale (c),

- currently implemented whose sales have already begun (i),

- planned whose sales will start in the next analyzed period (p). 
Therefore

$$
s=c+i+p
$$

Obtaining this type of information is not easy, however, because the Central Statistical Office publishes historical information. This applies to both data on the number of dwellings completed, commenced and sold. In addition, it should be noted that only dwellings that are for sale should be considered in order to make estimates. The CSO also does not publish information on the number of planned investments and dwellings included in these investments. On the other hand, private entities often have incomplete data (they conduct analyses based on selected economic entities). For this reason, it was necessary to carry out own research on all categories of the housing mentioned above (c, i, p, s). It was assumed that the planned apartments are those that would not appear in the developer's offer until the following analyzed period of time (month or year). It should be noted that the data for September 2020 were also collected, thanks to which it was possible to estimate the number of dwellings planned for August 2020. In addition, it should be noted that there are many planned investments that are only at the stage of obtaining a building permit. However, according to Siemińska (2013), this process can take more than 300 days in Poland (Siemińska, 2013), so it is assumed that they will not start until 2021.

Another limitation is the spatial extent of the study also resulting from its complexity. The study was conducted for the city of Łódź. This is the third largest city in Poland. It would seem that development activity should be well developed in this city. Meanwhile, in this respect Łódź occupied the last place among the six largest Polish cities for most of the time. This is mainly due to its location - not far from Warsaw (the capital of the country). Young people who are most often buyers of developers' dwellings decide to look for a job in the capital, because there they have greater career development opportunities, and above all higher wages. Besides, Łódź has a significant housing stock per 1,000 inhabitants (in 2018 - 524 dwellings/person, ranking second among the largest Polish cities after Warsaw - 548.8 dwellings/person). It may also be one of the reasons for the smaller activity of developers. The problem, however, is that Łódź's housing stock is largely in poor technical condition. Many buildings require major renovation or ought to be demolished. It should also be emphasized that such real estate often no longer meet the needs of the market due to the changing preferences of buyers. This could be considered as a field for developers, however, the majority of development investments in Poland are new construction. Łódź is also characterized by a large share of single-family investments and the large useful floor area of dwellings (see Antczak, 2013), which makes it an interesting research object from the point of view of the absorption rate. Namely, considering the above (population outflow, large housing stock), it would seem that these rates will be unfavorable 
for this city. However, a large number of development projects implemented in Łódź and the demand for them (the largest since the beginning of development activity in Poland, i.e. since the 1990s) suggest that the research will show the opposite trend. Therefore, the choice of this city was dictated by two aspects. First of all, the Lódź residential market is best known to the author because of previous research conducted in this area. Secondly, Łódź is a city quite specific in many respects.

The research was conducted on an annual basis in April 2018, 2019 and 2020 and on a monthly basis in June, July and August 2020 to check whether the absorption rate showed a rising or falling trend. Data were obtained from popular real estate market portals such as: rynekpierwotny.pl, urbanity.pl, noweinwestycje.pl, and the websites of individual developers. There is a risk of skipping investments that do not advertize on these websites or if the developer does not have its own website. The data were collected taking into account the locations where the investments were carried out and the forms of their development (singlefamily, multi-family). Łódź is divided into five districts: Bałuty, Górna, Polesie, Śródmieście and Widzew and such division is used in the research. Districts differed from one another in terms of area, development, utilities, and population density. Although the development of Śródmieście is quite dense, it is becoming increasingly popular, in accordance with the City's Integrated Spatial Development Concept 2020+, to locate investments between existing buildings, both in Śródmieście itself and in adjacent parts of other districts. Other research conducted by the author shows that about $45 \%$ of investments in 2018 were built along the city's main streets, i.e. Włókniarzy, Sikorskiego, Palki, and Kopcińskiego Street passing into Śmiegłego-Rydza Street and in the south into Broniewskiego Street (Antczak-Stępniak, 2020). This popularity of the Śródmieście district as a place for the implementation of developers' investments may translate into a decreasing absorption time of the dwellings located in them.

\section{Dynamics of housing market development in Lódź in 2018-2020 - the results}

\subsection{Lódź in comparison with the rest of the country (2015-2020)}

For a preliminary diagnosis of the situation in the Łódź housing market, several historical statistics were presented (Table 1).

Analysing the situation on a national scale, it should be noted that, above all, there is a visible surplus of supply over demand, i.e. more dwellings were commissioned than sold in the considered period. It should be noted that the difference between these variables was greater in the autumn and winter months. The smallest differences can be observed in the first 
half of the year. This applied to all of the analyzed years. The situation was somewhat different in relation to Łódź. In the autumn and winter months, supply exceeded demand, as was the case on a national scale, as at that time most investments were commissioned. In the following months, however, this relationship reversed, which was not observed in the case of nationwide data. In the first two quarters of the surveyed years, demand exceeded supply in Łódź, as buyers

Table 1. Basic statistics on development dwellings dwellings in Łódź against the background of Poland in the years 2015-2020*

\begin{tabular}{|c|c|c|c|c|c|c|c|c|}
\hline Specification & Dc Poland & Dc Łódź & $\begin{array}{l}\text { Share } \\
\text { of Łódź } \\
(3: 2)\end{array}$ & Ds Poland & Ds Łódź & $\begin{array}{l}\text { Share } \\
\text { of Łódź } \\
(6: 5)\end{array}$ & $\begin{array}{l}\text { D Poland } \\
(2-5)\end{array}$ & $\begin{array}{c}\text { D Łódź } \\
(3-6)\end{array}$ \\
\hline 1 & 2 & 3 & 4 & 5 & 6 & 7 & 8 & 9 \\
\hline I qtr. 2015 & 13,785 & 371 & 0.03 & 13,712 & 397 & 0.03 & 73 & -26 \\
\hline II qtr. 2015 & 15,343 & 221 & 0.01 & 13,106 & 337 & 0.03 & 2,237 & -116 \\
\hline III qtr. 2015 & 19,755 & 662 & 0.03 & 13,439 & 282 & 0.02 & 6,316 & 380 \\
\hline IV qtr. 2015 & 25,542 & 564 & 0.02 & 16,819 & 459 & 0.03 & 8,723 & 105 \\
\hline I qtr. 2016 & 19,584 & 88 & 0.00 & 16,917 & 528 & 0.03 & 2,667 & -440 \\
\hline II qtr. 2016 & 20,393 & 357 & 0.02 & 17,948 & 351 & 0.02 & 2,445 & 6 \\
\hline III qtr. 2016 & 21,321 & 174 & 0.01 & 15,249 & 344 & 0.02 & 6,072 & -170 \\
\hline IV qtr. 2016 & 30,218 & 1,053 & 0.03 & 13,481 & 407 & 0.03 & 16,737 & 646 \\
\hline I qtr. 2017 & 22,131 & 490 & 0.02 & 19,632 & 353 & 0.02 & 2,499 & 137 \\
\hline II qtr. 2017 & 22,108 & 351 & 0.02 & 18,543 & 399 & 0.02 & 3,565 & -48 \\
\hline III qtr. 2017 & 27,802 & 616 & 0.02 & 16,025 & 651 & 0.04 & 11,777 & -35 \\
\hline IV qtr. 2017 & 32,986 & 637 & 0.02 & 13,023 & 386 & 0.03 & 19,963 & 251 \\
\hline I qtr. 2018 & 25,548 & 492 & 0.02 & 21,788 & 534 & 0.03 & 3,760 & -42 \\
\hline II qtr. 2018 & 22,480 & 336 & 0.01 & 19,943 & 904 & 0.02 & 2,537 & -568 \\
\hline III qtr. 2018 & 29,726 & 829 & 0.03 & 18,279 & 551 & 0.04 & 11,447 & 278 \\
\hline IV qtr. 2018 & 34,563 & 838 & 0.02 & 21,211 & 709 & 0.03 & 13,352 & 129 \\
\hline I qtr. 2019 & 28,768 & 930 & 0.02 & & & & & \\
\hline II qtr. 2019 & 30,002 & 885 & 0.03 & & & & & \\
\hline III qtr. 2019 & 32,401 & 875 & 0.03 & & & & & \\
\hline IV qtr. 2019 & 40,264 & 1,132 & 0.03 & & & & & \\
\hline I qtr. 2020 & 30,768 & 1,555 & 0.03 & & & & & \\
\hline II qtr. 2020 & 32,110 & 973 & 0.05 & & & & & \\
\hline
\end{tabular}

* On the date of the survey, data on dwelling sales in 2019 were not yet available.

Dc Poland - dwellings completed in Poland.

Ds Poland - dwellings sold on the primary market in Poland.

Dc Łódź - dwellings completed in Łódź.

Ds Łódź - dwellings sold on the primary market in Łódź.

D - difference.

Source: own elaboration based on the Local Data Bank. 
were more willing to buy ready-to-use properties. At the same time, many new investments were started in the second quarter and those in a good location or with interesting architecture found buyers at the "hole in the ground" stage. The way data for Łódź differs from national data is another proof of the city's specificity. Table 1 also presents the share of Łódź dwellings completed and sold in the total number of dwellings completed and sold in Poland, as well as the differences between these categories which have already been discussed.

\subsection{The developer housing market in Lódź (2018-2020)}

As mentioned in the previous Section, the information published by the Local Data Bank of the Central Statistical Office of Poland is not sufficient for the analysis of the absorption rate, therefore, in-depth own research in this area was carried out. In the period from June to August 2020, developer investments in which dwellings for sale were still available were analyzed monthly. 90 developers operating in the Łódź residential market and 162 investments (investment stages) were analyzed, of which 28 were single-family investments. To compare, the survey was conducted also on an annual basis i.e. in April 2018, 2019 and 2020. At that time, the offer included the dwellings of 102 developers resulting from 225 investments (different investment stages). Some of the investments from 2018 were already sold out in full. Many others have also been launched. Detailed statistics related to the analysed undertakings are presented below in Table 2 .

Table 2. Developer dwellings offered for sale and sold in Łódź in selected months of 2018-2020

\begin{tabular}{|c|c|c|c|c|c|c|c|c|c|c|c|}
\hline \multirow[t]{2}{*}{ No. } & \multirow[t]{2}{*}{ Content } & \multicolumn{3}{|c|}{ Absolute values } & \multicolumn{2}{|c|}{$\begin{array}{c}\text { Chain dynamics } \\
\text { indexes } \\
(\mathrm{t}-1=100)\end{array}$} & \multicolumn{3}{|c|}{ Absolute values } & \multicolumn{2}{|c|}{$\begin{array}{c}\text { Chain dynamics } \\
\text { indexes } \\
(\mathrm{t}-1=100)\end{array}$} \\
\hline & & $\begin{array}{c}\text { IV } \\
2018 \\
\end{array}$ & $\begin{array}{c}\text { IV } \\
2019\end{array}$ & $\begin{array}{c}\text { IV } \\
2020\end{array}$ & \begin{tabular}{|c|} 
IV \\
$2019 / 2018$ \\
\end{tabular} & $\begin{array}{c}\text { IV } \\
2020 / 2019\end{array}$ & $\begin{array}{c}\text { VI } \\
2020\end{array}$ & $\begin{array}{c}\text { VII } \\
2020\end{array}$ & $\begin{array}{r}\text { VIII } \\
2020 \\
\end{array}$ & $\begin{array}{l}\text { VII/ } \\
\text { VI }\end{array}$ & $\begin{array}{l}\text { VIII/ } \\
\text { VII }\end{array}$ \\
\hline 1 & $\begin{array}{l}\text { All dwellings } \\
\text { in investments }\end{array}$ & 9,549 & 13,923 & 13,023 & $46 \%$ & $-6 \%$ & 12,784 & 13,030 & 13,510 & $2 \%$ & $4 \%$ \\
\hline 2 & Dwellings sold & 5,596 & 8,985 & 8,205 & $60 \%$ & $-9 \%$ & 7,544 & 7,789 & 8,030 & $3 \%$ & $3 \%$ \\
\hline 3 & Share $(2: 1)$ & $59 \%$ & $64 \%$ & $63 \%$ & & & $59 \%$ & $60 \%$ & $59 \%$ & & \\
\hline 4 & Dwellings for sale & 3,953 & 4,938 & 4,818 & $25 \%$ & $-2 \%$ & 5,240 & 5,241 & 5,480 & $0 \%$ & $4 \%$ \\
\hline 5 & Share $(4: 1)$ & $41 \%$ & $36 \%$ & $37 \%$ & & & $41 \%$ & $40 \%$ & $41 \%$ & & \\
\hline
\end{tabular}

Source: own study.

According to the data presented in Table 2, 2019 was the best period in terms of the number of completed and under construction dwellings. At that time, there was a $46 \%$ increase 
in their number compared to 2018. Increases were also recorded in the number of dwellings sold. In April 2020, there was a decline in both housing categories (at 6-9\%). In the period from June to August 2020, there was a slight increase in the number of dwellings completed and under construction by developers, and thus dwellings on sale (in August an increase of 4\% compared to July 2020). Furthermore, sales remain relatively constant.

Table 3. Structure of the researched dwellings by the type of buildings

\begin{tabular}{|c|c|c|c|c|c|c|}
\hline Specification & April 2018 & April 2019 & April 2020 & June 2020 & July 2020 & August 2020 \\
\hline \multicolumn{7}{|c|}{ Multi-family } \\
\hline $\begin{array}{l}\text { All dwellings } \\
\text { in investments }\end{array}$ & $\begin{array}{c}9,052 \\
(94 \\
\text { investments) }\end{array}$ & $\begin{array}{c}13,408 \\
(142 \\
\text { investments) }\end{array}$ & $\begin{array}{c}12,538 \\
(125 \\
\text { investments) }\end{array}$ & $\begin{array}{c}12,263 \\
(126 \\
\text { investments) }\end{array}$ & $\begin{array}{c}12,559 \\
(126 \\
\text { investments })\end{array}$ & $\begin{array}{c}13,023 \\
(128 \\
\text { investments })\end{array}$ \\
\hline Dwellings sold & 5,278 & 8,639 & 7,866 & 7,231 & 7,504 & 7,723 \\
\hline Dwellings for sale & 3,774 & 4,769 & 4,672 & 5,032 & 5,055 & 5,300 \\
\hline \multicolumn{7}{|c|}{ Single-family } \\
\hline $\begin{array}{l}\text { All dwellings } \\
\text { in investments }\end{array}$ & $\begin{array}{c}497 \\
(20 \\
\text { investments })\end{array}$ & $\begin{array}{c}515 \\
(23 \\
\text { investments) }\end{array}$ & $\begin{array}{c}485 \\
(23 \\
\text { investments })\end{array}$ & $\begin{array}{c}521 \\
(26 \\
\text { investments) }\end{array}$ & $\begin{array}{c}471 \\
(26 \\
\text { investments })\end{array}$ & $\begin{array}{c}487 \\
(27 \\
\text { investments) }\end{array}$ \\
\hline Dwellings sold & 318 & 346 & 339 & 313 & 285 & 307 \\
\hline Dwellings for sale & 179 & 169 & 146 & 208 & 186 & 180 \\
\hline
\end{tabular}

Source: own elaboration.

The predominance of multi-family investments over single-family ones (Table 3 ) is visible in all of the surveyed months (94-96\%). The month with the largest number of development projects (implemented and commissioned) in multi-family buildings in the current year of 2020 was August, and in single-family ones - June of 2020, but April 2019 stood out in particular among all of the analyzed periods. At that time, also dwellings sold both in multi-family and single-family investments had the highest values.

Table 4. Structure of the researched dwellings by city districts

\begin{tabular}{|c|c|c|c|c|c|c|}
\hline Specification & April 2018 & April 2019 & April 2020 & June 2020 & July 2020 & August 2020 \\
\hline 1 & 2 & 3 & 4 & 5 & 6 & 7 \\
\hline \multicolumn{7}{|c|}{ Bałuty } \\
\hline $\begin{array}{l}\text { All dwellings } \\
\text { in investments }\end{array}$ & $\begin{array}{c}2,323 \\
(27 \\
\text { investments })\end{array}$ & $\begin{array}{c}3,432 \\
(40 \\
\text { investments })\end{array}$ & $\begin{array}{c}3,482 \\
(40 \\
\text { investments) }\end{array}$ & $\begin{array}{c}3,329 \\
(42 \\
\text { investments })\end{array}$ & $\begin{array}{c}3,329 \\
(42 \\
\text { investments })\end{array}$ & $\begin{array}{c}3,228 \\
(40 \\
\text { investments })\end{array}$ \\
\hline Dwellings sold & 1,479 & 2,283 & 2,015 & 1,794 & 1,838 & 1,783 \\
\hline Dwellings for sale & 844 & 1,149 & 1,467 & 1,535 & 1,491 & 1,445 \\
\hline
\end{tabular}




\begin{tabular}{|c|c|c|c|c|c|c|}
\hline 1 & 2 & 3 & 4 & 5 & 6 & 7 \\
\hline \multicolumn{7}{|c|}{ Polesie } \\
\hline $\begin{array}{l}\text { All dwellings } \\
\text { in investments }\end{array}$ & $\begin{array}{c}2,313 \\
(38 \\
\text { investments) }\end{array}$ & $\begin{array}{c}3,346 \\
(50 \\
\text { investments }) \\
\end{array}$ & $\begin{array}{c}3,098 \\
(37 \\
\text { investments) }\end{array}$ & $\begin{array}{c}2,897 \\
(34 \\
\text { investments) }\end{array}$ & $\begin{array}{c}3,206 \\
(36 \\
\text { investments) }\end{array}$ & $\begin{array}{c}3,375 \\
(38 \\
\text { investments })\end{array}$ \\
\hline Dwellings sold & 1,264 & 2,099 & 1,739 & 1,697 & 1,865 & 1,922 \\
\hline Dwellings for sale & 1,049 & 1,247 & 1,359 & 1,200 & 1,341 & 1,453 \\
\hline \multicolumn{7}{|c|}{ Górna } \\
\hline $\begin{array}{l}\text { All dwellings } \\
\text { in investments }\end{array}$ & $\begin{array}{c}1,355 \\
(16 \\
\text { investments })\end{array}$ & $\begin{array}{c}1,130 \\
(20 \\
\text { investments })\end{array}$ & $\begin{array}{c}1,371 \\
(20 \\
\text { investments })\end{array}$ & $\begin{array}{c}1,401 \\
(24 \\
\text { investments) }\end{array}$ & $\begin{array}{c}1,457 \\
(23 \\
\text { investments })\end{array}$ & $\begin{array}{c}1,457 \\
(23 \\
\text { investments })\end{array}$ \\
\hline Dwellings sold & 640 & 754 & 620 & 584 & 668 & 708 \\
\hline Dwellings for sale & 715 & 376 & 751 & 817 & 789 & 749 \\
\hline \multicolumn{7}{|c|}{ Widzew } \\
\hline $\begin{array}{l}\text { All dwellings } \\
\text { in investments }\end{array}$ & $\begin{array}{c}2,034 \\
(22 \\
\text { investments })\end{array}$ & $\begin{array}{c}3,804 \\
(38 \\
\text { investments) }\end{array}$ & $\begin{array}{c}3,317 \\
(35 \\
\text { investments })\end{array}$ & $\begin{array}{c}2,929 \\
(32 \\
\text { investments) }\end{array}$ & $\begin{array}{c}2,879 \\
(32 \\
\text { investments) }\end{array}$ & $\begin{array}{c}3,291 \\
(35 \\
\text { investments) }\end{array}$ \\
\hline Dwellings sold & 1,433 & 2,492 & 2,391 & 1,937 & 1,941 & 2,067 \\
\hline Dwellings for sale & 601 & 1,312 & 926 & 992 & 938 & 1,224 \\
\hline \multicolumn{7}{|c|}{ Śródmieście } \\
\hline $\begin{array}{l}\text { All dwellings } \\
\text { in investments }\end{array}$ & $\begin{array}{c}1,524 \\
(11 \\
\text { investments) }\end{array}$ & $\begin{array}{c}2,211 \\
(17 \\
\text { investments) }\end{array}$ & $\begin{array}{c}1,755 \\
(16 \\
\text { investments })\end{array}$ & $\begin{array}{c}2,228 \\
(20 \\
\text { investments })\end{array}$ & $\begin{array}{c}2,159 \\
(19 \\
\text { investments) }\end{array}$ & $\begin{array}{c}2,159 \\
(19 \\
\text { investments) }\end{array}$ \\
\hline Dwellings sold & 780 & 1,357 & 1,440 & 1,532 & 1,477 & 1,550 \\
\hline Dwellings for sale & 744 & 854 & 315 & 696 & 682 & 609 \\
\hline
\end{tabular}

Source: own elaboration.

According to the data contained in Table 4, the number of investments in individual city districts varies. In August 2020, the largest number of dwellings offered for sale in the analyzed investments was recorded in Polesie (in 2019, in Widzew - the largest among the city districts). Bałuty came second. Meanwhile, the largest number of dwellings sold at the same time was recorded in the Widzew and Polesie districts and the smallest number in the Górna district (in 2018-2019, the smallest number of dwellings sold was recorded also in the Górna district).

\subsection{Development of absorption rates for developer housing in Lódź in 2018-2020}

The absorption rate was calculated for all dwellings together and by also taking into account the building form and the investment location by district. In order to reliably interpret the research results related to the examined indicator, one must first answer the question of what the rational time of absorption of the newly created housing supply is? This time is a critical element of the entire enterprise budget. Thanks to it, developers are aware of how 
long afterwards they can expect a return on invested funds and profit. There is no universally applicable standard specifying what period should be acceptable. Nevertheless, it is assumed that good investments sell for about a year, and to this period, there should be added a reserve in the case of unexpected delays or institutional and general economic changes that could negatively affect sales. Therefore, the period of 16-18 months seems to be the most realistic absorption period (Peiser, Hamilton, 2012).

Table 5. Absorption rates for developer housing in Łódź in the analysed months of 2018-2020

\begin{tabular}{|c|c|c|c|c|c|}
\hline Specification & $\begin{array}{l}\text { Commissioned (c) }+ \\
\text { implemented (i) } \\
\text { for sale }\end{array}$ & $\begin{array}{l}\text { Planned (p) } \\
\text { for sale }\end{array}$ & $\begin{array}{c}\text { Total } \\
(1+2)\end{array}$ & $\begin{array}{l}\text { Number of dwellings } \\
\text { sold in relation } \\
\text { to the previous month* }\end{array}$ & $\begin{array}{c}\text { Absorption } \\
\text { rates (AR) } \\
(4: 5)\end{array}$ \\
\hline 1 & 2 & 3 & 4 & 5 & 6 \\
\hline April 2018 & 3,953 & 5,069 & 9,022 & & \\
\hline April 2019 & 4,938 & 4,191 & 9,129 & 4,024 & 2.27 \\
\hline April $2020^{* *}$ & 4,818 & 1,223 & 6,041 & 3,962 & \\
\hline June $2020^{* * * *}$ & 5,240 & 397 & 5,637 & $743: 2=371.5$ & 15.17 \\
\hline July 2020 & 5,241 & 611 & 5,852 & 396 & 14.78 \\
\hline August 2020 & 5,480 & 524 & 6,004 & 372 & 16.14 \\
\hline
\end{tabular}

* In the case of April, it was counted in relation to the previous year (April 2019, April 2020).

** In order to maintain the comparability of data, the annual data (April 2021) should be adopted in the category of the number of planned dwellings and in total. Due to their lack at this point, the absorption rate has not been estimated. The data contained in the table refer to June 2020 and they are provided for information purposes only.

${ }^{* * *}$ the change in the number of dwellings sold between June and April 2020 amounts to 743 dwellings. Due to the interval of two months, the number of dwellings sold in June compared to the previous period was assumed to be half of this value.

Source: own elaboration.

The data presented in Table 5 show that the absorption period in Łódź is shortening. In 2019, it was about 27 months, (taking into account all dwellings regardless of the type of buildings and their location), while in the analyzed months of 2020 it was about 14-16 months. It should be noted that sales of developer dwellings in 2019 were large, but at the same time many investments were planned, which increased the absorption period. The decreasing absorption rate in the following months was encouraging developers to build new dwellings.

Taking into account the division of dwellings by their building type (Table 6), in the analyzed months of 2020, the absorption rate for single-family houses was lower than for multi-family housing. However, this trend was reversed in the years 2018-2019. This is due to a significant increase in the sale of houses with their "own plot", their own green space, during the COVID-19 pandemic. 
Table 6. Absorption rates in Łódź in the examined months taking into account the type of buildings

\begin{tabular}{|c|c|c|c|c|c|}
\hline Specification & $\begin{array}{l}\text { Commissioned (c) }+ \\
\text { implemented (i) } \\
\text { for sale }\end{array}$ & $\begin{array}{l}\text { Planned (p) } \\
\text { for sale }\end{array}$ & $\begin{array}{c}\text { Total } \\
(1+2)\end{array}$ & $\begin{array}{l}\text { Number of dwellings } \\
\text { sold in relations } \\
\text { to the previous month* }\end{array}$ & $\begin{array}{l}\text { Absorption } \\
\text { rates } \\
(4: 5)\end{array}$ \\
\hline 1 & 2 & 3 & 4 & 5 & 6 \\
\hline \multicolumn{6}{|c|}{ Single-family } \\
\hline April 2018 & 179 & 146 & 325 & & \\
\hline April 2019 & 169 & 221 & 390 & 137 & 2.85 \\
\hline April $2020^{* * *}$ & 146 & 130 & 276 & 233 & \\
\hline June $2020^{* * *}$ & 208 & 4 & 212 & $68: 2=34$ & 6.23 \\
\hline July 2020 & 186 & 16 & 202 & 26 & 7.77 \\
\hline August 2020 & 180 & 28 & 208 & 22 & 9.45 \\
\hline \multicolumn{6}{|c|}{ Multi-family } \\
\hline April 2018 & 3,774 & 4,923 & 8,697 & & \\
\hline April 2019 & 4,769 & 3,970 & 8,739 & 3,887 & 2.25 \\
\hline April $2020^{* *}$ & 4,672 & 1,093 & 5,765 & 3,729 & \\
\hline June $2020^{* * * *}$ & 5,032 & 393 & 5,425 & $675: 2=337.5$ & 16.07 \\
\hline July 2020 & 5,055 & 595 & 5,650 & 370 & 15.27 \\
\hline August 2020 & 5,300 & 496 & 5,796 & 350 & 16.56 \\
\hline
\end{tabular}

*As in Table 5.

** as in Table 5.

**** as in Table 5 .

Source: own elaboration.

Absorption rates also showed very significant differences between the Łódź districts (Table 7). First, it can be seen that in 2019, developer dwellings were selling at the fastest rate in the Śródmieście district (the central part of the city) and the Widzew district. There was a change in the following months, and in June 2020, it was in Polesie that developers sold their real estate the fastest. It should be noted, however, that this district also covers a significant part of the central areas of the city, and recently, in accordance with the Integrated Concept for the Spatial Development of Łódź 2020+ assuming the inner development of the city, the number of investments implemented in central locations of Łódź has been increasing significantly. In August 2020 the absorption rate was the smallest in the Śródmieście and Widzew districts again. Secondly, in the Bałuty district, the absorption rate in the period June-August 2020 was relatively constant (changes of 3-4\%). In other districts, these changes were much greater. A downward trend in the holiday season of 2020 in relation to the absorption rate was recorded in the Widzew district (decline even over 50\%), while in Polesie, where a lot of new investments 
Table 7. Absorption rates in Łódź in the analysed months by city districts

\begin{tabular}{|c|c|c|c|c|c|}
\hline Specification & $\begin{array}{l}\text { Commissioned (c) } \\
+ \text { implemented (i) } \\
\text { for sale }\end{array}$ & $\begin{array}{l}\text { Planned }(p) \\
\text { for sale }\end{array}$ & $\begin{array}{c}\text { Total } \\
(1+2)\end{array}$ & $\begin{array}{l}\text { Number of dwellings } \\
\text { sold in relation } \\
\text { to the previous month* }\end{array}$ & $\begin{array}{l}\text { Absorption } \\
\text { rates } \\
(4: 5)\end{array}$ \\
\hline 1 & 2 & 3 & 4 & 5 & 6 \\
\hline \multicolumn{6}{|c|}{ Bałuty } \\
\hline April 2018 & 844 & 1,119 & 1,963 & & \\
\hline April 2019 & 1,149 & 1,201 & 2,350 & 814 & 2.89 \\
\hline April $2020^{* *}$ & 1,467 & 162 & 1,629 & 819 & \\
\hline June $2020^{* * *}$ & 1,535 & 0 & 1,535 & $94: 2=47$ & 32.66 \\
\hline July 2020 & 1,491 & 0 & 1,491 & 44 & 33.88 \\
\hline August 2020 & 1,445 & 54 & 1,499 & 46 & 32.59 \\
\hline \multicolumn{6}{|c|}{ Górna } \\
\hline April 2018 & 715 & 245 & 960 & & \\
\hline April 2019 & 376 & 813 & 1,189 & 524 & 2.27 \\
\hline April $2020^{* *}$ & 751 & 150 & 901 & 438 & \\
\hline June $2020^{* * *}$ & 817 & 84 & 901 & $66: 2=33$ & 27.30 \\
\hline July 2020 & 789 & 0 & 789 & 112 & 7.04 \\
\hline August 2020 & 749 & 109 & 858 & 40 & 21.45 \\
\hline \multicolumn{6}{|c|}{ Polesie } \\
\hline April 2018 & 1,049 & 1,047 & 2,096 & & \\
\hline April 2019 & 1,247 & 1,167 & 2,414 & 849 & 2.84 \\
\hline April $2020^{* *}$ & 1,359 & 239 & 1,598 & 1,007 & \\
\hline June $2020^{* * *}$ & 1,200 & 309 & 1,509 & $358: 2=179$ & 8.43 \\
\hline July 2020 & 1,341 & 199 & 1,540 & 168 & 9.17 \\
\hline August 2020 & 1,453 & 74 & 1,527 & 87 & 17.55 \\
\hline \multicolumn{6}{|c|}{ Śródmieście } \\
\hline April 2018 & 744 & 822 & 1,566 & & \\
\hline April 2019 & 854 & 378 & 1,232 & 712 & 1.73 \\
\hline April $2020^{* *}$ & 315 & 534 & 849 & 707 & \\
\hline June $2020^{* * *}$ & 696 & 0 & 696 & $153: 2=76.5$ & 9.10 \\
\hline July 2020 & 682 & 0 & 682 & 14 & 48.71 \\
\hline August 2020 & 609 & 153 & 762 & 73 & 10.44 \\
\hline \multicolumn{6}{|c|}{ Widzew } \\
\hline April 2018 & 601 & 1,836 & 2,437 & & \\
\hline April 2019 & 1,312 & 632 & 1,944 & 1,125 & 1.73 \\
\hline April $2020^{* *}$ & 926 & 138 & 1,064 & 991 & \\
\hline June $2020^{* * *}$ & 992 & 4 & 996 & $72: 2=36$ & 27.67 \\
\hline July 2020 & 938 & 412 & 1,350 & 58 & 23.27 \\
\hline August 2020 & 1,224 & 134 & 1,358 & 126 & 10.78 \\
\hline
\end{tabular}

"As in Table 5.

${ }^{* *}$ as in Table 5 .

$* * *$ as in Table 5.

Source: own elaboration. 
have recently been created, the indicator increased from month to month. In the other two districts with the lowest number of new dwellings, the absorption rate fluctuated significantly the changes that took place between June and August 2020 reached even over $400 \%$ in the Śródmieście district. Perhaps high prices (Śródmieście) or less interest in the location (Górna) mean that when a new offer appears on the market, potential buyers retain a certain restraint, wanting to compare these dwellings with others.

As a relatively short period of time has been analyzed, it is difficult to talk about clear trends here. However, the presented absorption ratios show (although it should be approached with some caution) that in the Polesie district developers should be careful because many investments resulted in a slight increase in the absorption rate, and that the interest of buyers in the Widzew district is growing.

\section{Discussion}

Is it possible to say, based on the analyses, that the absorption rate is an important tool for assessing the dynamics of housing market development? According to the author, the answer is clear: yes. It shows whether the sale time of dwellings in a given city is getting longer or shorter. Based on the case of Łódź, it is also visible that this ratio differs with regard to the type of building and the detailed location. The absorption rate is, therefore, relevant information for a developer who makes decisions on its basis whether to engage in another venture or maybe this is not a good time to freeze his/her capital. In addition, it allows developers to determine which location, form of development, as well as size of dwellings is most desirable from the point of view of a potential buyer. Nevertheless, the problem in Poland is access to reliable and, above all, up-to-date information on the number of dwellings delivered, started and planned, as well as the number of dwellings sold. This requires developers to collect and process the necessary source information, which significantly impedes conducting this activity in Poland. Therefore, one should aim at accelerating the process of publishing data in the Central Statistical Office, expanding their scope or creating a database dedicated to developers (e.g. by the Polish Association of Developers) in order to facilitate their calculation for the absorption rate (by the location and type of buildings), so important in assessing the dynamics of real estate market development. It is also important from the point of view of financing institutions, as this kind of data informs them about how quickly they will be able to regain the capital involved in individual development projects. 


\section{Conclusions}

To sum up, this article is a contribution to the body of knowledge, especially regarding emerging countries or even post-socialist countries, serving to emphasize the importance of market analysis, and in particular the estimation of the absorption rate. Due to the fact that the real estate market in post-socialist countries is still developing, new legal regulations are often introduced or the existing ones are changed, and as a result, the risk of conducting development activity is quite high. Market analysis, including estimation of the absorption rate, should help to some extent in reducing this risk. However, often development entities do not have adequate knowledge about what individual elements of this analysis should look like to be actually effective. Therefore, the article clearly presents the method of estimating such an indicator. In addition, an important contribution is also the use of property divisions by location and type of development when estimating this ratio. There are no such analyses in Poland, and the conducted research clearly shows a large diversity in this respect.

The research carried out in this article has also practical applications. The results of this research can be directly used by developers operating in Łódź. They should first of all raise awareness of the volatility of the real estate market, but also help to make decisions about where and what type of property is best to invest in.

It should be remembered, however, that the high significance of the absorption rate discussed for development activity, in conjunction with limited access to public information and the number of restrictions that result from a single survey, indicate the need for further analysis in this regard. This applies above all to the fact that such analyses should be carried out in a continuous manner, and it also seems important to increase their spatial coverage. From the developer's point of view, it also seems important to conduct such research taking into account the size of the dwellings being analysed.

\section{References}

Antczak A. (2013). Developers' Activity in Selected Cities of Poland - A Comparative Analysis, Real Estate Management and Valuation, 21 (1), 59-68. DOI: https://doi.org/10.2478/ remav-2013-0008. 
Antczak-Stępniak, A. (2019). A market analysis in development activity. The problem of the availability of statistical data in European countries, Real Estate Management and Valuation, 26 (4), 35-44, DOI: https://doi.org/10.2478/remav-2018-0034.

Antczak-Stępniak A. (2020). Location tendencies in developer investments in the residential market in Łódź, Bulletin Of Geography. Socio-economic Series, 47, 133-144, DOI: $10.1515 / 20301$.

Begg, D., Fisher, S., Dornbusch, R. (1993). Ekonomia. Warszawa: Państwowe Wydawnictwo Ekonomiczne.

Boyd, G. (2018). Survey of Market Absorption of New Multifamily Units. 2018 Annual Absorption Report (2017 Absorptions for 2016 Completions). U.S. Census Bureau.

Creedy, J., Wall, N.F. (1979). Real Estate Investment by Objective. US: McGraw-Hill Book Company.

Dąbrowski, M., Kirejczyk, K. (2001). Inwestycje deweloperskie. Warszawa: TWIGGER.

Delauney, N., Burton, J., Talpade S. (2011). Supply and demand analysis of single-family residential units in Carroll County, Georgia. Research in Business and Economics Journal. Retrieved from: https://www.aabri.com/manuscripts/10735.pdf.

Dziworska, K., Trojanowski, D. (2006). Struktura procesu inwestycyjnego projektów deweloperskich. In: A. Nalepka (ed.), Inwestycje i nieruchomości (pp. 42-46). Kraków: Akademia Ekonomiczna w Krakowie.

Eldred, G.W. (1987). Real Estate: Analysis and Strategy, Harper \& Row.

Floyd, Ch.F., Allen, M.T. (1987). Real Estate Principles. Chicago: Dearborn Financial Publishing Inc.

Frino, A., Lepone, A., Mollica, V., Vassallo, A. (2010). The Impact of Auctions on Residential Sale Prices: Australian Evidence. Australasian Accounting, Business and Finance Journal, 4 (3), 3-22.

Geipele, I., Kauškale, L. (2013). The Influence of Real Estate Market Cycle on the Development in Latvia. Procedia Engineering, 57, 327-333. DOI: 10.1016/j.proeng.2013.04.044.

Gelain, P., Lansing, K.J., Natvik, G.J. (2018). Explaining the Boom-Bust Cycle in the U.S. Housing Market: A Reverse-Engineering Approach, Federal Reserve Bank of San Francisco, Working Paper Series.

Gibson, H.J., Li, Y. (2013). Opportunities for the United States condominium foreclosure market to provide amenable affordable housing options: The case of Tampa/Hillsborough, Florida. Urbani izziv, 24 (1), 90-106. DOI: 10.5379/urbani-izziv-en-2013-24-01-001.

Glaeser, E.L. (2017). Real Estate Bubbles and Urban development. Asian Development Review, 34 (2), 114-151. DOI: 10.1162/adev_a_00097.

Greer, G.E., Kolbe, P.T. (2003). Investment Analysis for Real Estate Decisions. 1, 5th edition, DearbornTM Real Estate Education. 
Havard, T. (2014). Financial feasibility studies for property development. Theory and practice. London: Routledge.

Henneberry, J. (1987). Property market definition: a fundamental problem. Property Management, 5 (1), 35-42.

Keim, L.K. (2007). The Fundamentals of Listing and Selling Commercial Real Estate. West Conhohocken: Infinity Publishing.

Kucharska-Stasiak, E. (2016). Ekonomiczny wymiar nieruchomości. Warszawa: PWN.

Land Absorption Study. City of Chico (2018) BAE Urban Economics. Retrieved from: http://www.chico.ca.us/_includes/documents/CityofChico_LandAbsorptionStudy_FINAL_07-24-18.pdf.

Letwin, O. (2018). Independent Review of Build Out Rates. Final Report. Retrieved from: https://assets.publishing.service.gov.uk/government/uploads/system/uploads/attachment data/file/752124/Letwin_review_web_version.pdf.

Lipiński, J. (2000). Marketing nieruchomości. Nieruchomości C.H. Beck, 6.

McAllister, P., Nase, I. (2020). The accuracy of consensus real estate forecasts revisited. Journal of Property Research, 37 (2), 147-170. DOI: 10.1080/09599916.2020.1720784.

Millington, A.F. (2000). Property development. London and New York: Routledge.

Mueller, G., Pevnev, A. (1997). An Analysis of Rental Growth Rates During Different Points in the Real Estate Market Cycle. Florida: The American Real Estate Society Meetings Sarasota.

Mueller, G. (2001). Predicting Long-Term Trends \& Market Cycles in Commercial Real Estate. Working Paper \#388.

Narodowy Bank Polski (2019). Raport o sytuacji na rynkach nieruchomości mieszkaniowych $i$ komercyjnych w Polsce w 2018 roku. Warszawa. Retrieved from: https://www.nbp.pl/ publikacje/rynek_nieruchomosci/raport_2018.pdf.

Novak, L.R. (1996). Market and feasibility studies: a how - to guide. Retrieved from: https:// pages.uoregon.edu/rgp/PPPM613/downloads/How\%20to\%20do\%20a\%20Market\%20 Analysis.pdf.

Pivo, G. (2006). Timing Real Estate Cycles. Patient Capital and School Trust Real Estate Programs. Lincoln Institute of Land Policy.

Perera, T., Higgins, D., Wong, W.W. (2018). The evaluation of the Australian office market forecast accuracy. Journal of Property Investment \& Finance, 36 (3), 259-272. DOI: https:// doi.org/10.1108/JPIF-04-2017-0029.

Peiser, R.B., Hamilton, D. (2012). Professional Real Estate Development. Washington: The ULI Guide to the business, Urban Land Institute. 
Raslanas, S., Siniak, N., Shavrov, S., Rogova, O., Zinkina, D. (2015). Real estate development. In: A. Kaklauskas, E.K. Zavadskas, R. Dargis, D. Bardauskiené (ed.), Sustainable development of real estate (pp. 127-231). Vilnius: VGTU Press TECHNICA.

Reed, R., Wu, H. (2010). Understanding property cycles in a residential market. Property management, 28 (1), 33-46. DOI: 10.1108/02637471011017163.

Rottke, N., Wernecke, M. (2002). Real Estate Cycles in Germany - Causes, Empirical Analysis and Recommendations for the Management Decision Process. New Zealand: Paper presented at the 8th Conference of the Pacific Rim Real Estate Society 21-23 January 2002 Christchurch.

REAS (2017). Rynek mieszkaniowy w Polsce - I kwartat 2017 r. Warszawa. Retrieved from: http://www.reas.pl/publikacje?page=1\#.

Siemińska, E. (2013). Ryzyka inwestowania i finansowania na rynku nieruchomości w kontekście etyki $i$ społecznej odpowiedzialności. Toruń: Wydawnictwo Naukowe Uniwersytetu Mikołaja Kopernika.

Smith, Ch.A, Verma, R., Manrique, J. (2012). Using Historical Employment Data to Forecast Absorption Rates and Rents in the Apartment Market. Real Estate Issue, 37 (2-3), 31-37.

Tse, R., Webb, J. (2003). Models of Office Market Dynamics. Urban Studies, 40 (1), 71-89. DOI: $10.1080 / 00420980220080171$.

Żelazowski, K. (2017). Housing Market Cycles in the Context of Business Cycles. Real Estate Management and Valuation, 25 (3), 5-14. DOI: 10.1515/remav-2017-0017.

\section{Citation}

Antczak-Stępniak, A. (2021). Absorption Rate as a Tool for Assessing the Dynamics of Development Activity. Folia Oeconomica Stetinensia, 21 (2), 1-20. DOI: 10.2478/foli-2021-0013. 